Copyright (C) 2021 by Cherkas Global University

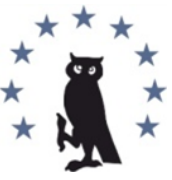

Published in the USA

Russkii Arkhiv

Has been issued since 1863 .

E-ISSN: 2413-726X

2021. 9(2): 197-209

DOI: $10.13187 /$ ra.2021.2.197

https://ra.cherkasgu.press

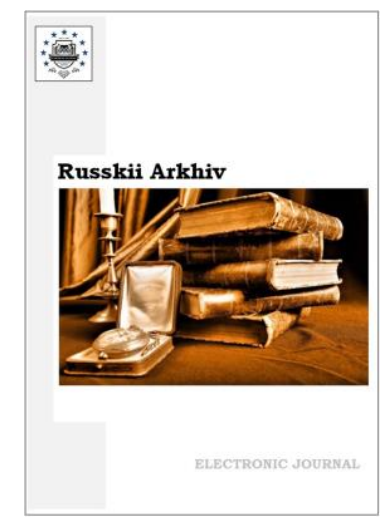

\title{
Zekerya Asanov's Memories about the Holocaust, Deportation, the Commandant's Regime, as Well as about the Good People with Whom Life Brought Him Together
}

Preparation for publication, introductory article and comments

Vladimir E. Polyakov ${ }^{a}$,

a Crimean Engineering and Pedagogical University named after Fevzi Yakubov, Simferopol, Russian Federation

\begin{abstract}
Memories of the Crimean Tatars were rarely published in the Soviet times. Nowadays, memoirs are often published without scientific editing and commentaries. The memoirs of Z. Asanov, a witness to the tragic events of the Great Patriotic War and the post-war period are published for the first time. The author of the memoirs was eyewitnesses to the extermination of Jews in Yevpatoria, occupied by the German-Romanian troops. Later, together with his relatives and fellow countrymen, he was deported. Much attention is paid to the description of the life of the exile settlers in the conditions of the commandant's regime, life in orphanages in Uzbekistan. Along with the difficulties he experienced, Z. Asanov emphasizes the atmosphere of mutual assistance and fraternal help from not only the Crimean Tatars, but also representatives of other nationalities - Uzbeks, Tajiks, Russians, with whom the fate brought him together.

Keywords: Great Patriotic War, Holocaust, Evpatoria, deportation, Uzbekistan, Tajikistan, commandant's regime, orphanage.

В силу целого комплекса причин, главной из которых была депортация крымскотатарского народа, длившаяся без малого полвека, воспоминания крымских татар публиковались крайне редко. В поздний советский период (с 1964 г. по 1991 г.) в Ташкенте на крымскотатарском языке был издан ряд воспоминаний: 3. Ниязиева-Керменчикли (Ниязиев-Керменчикли, 1971), Э.У. Чалбаша (Чалбаш, 1971), А. Молла (Молла, 1978) А.-А.Эмирова (Эмиров, 1983). Все - на крымскотатарском языке. Исключением стали изданные на русском языке мемуары Э. Арифова (Эрифов, 1990). В период с 1991 по 2014 гг., уже после возвращения на родину вышли: на русском языке - воспоминания Э.У. Чалбаша (Чалбаш, 1996, 2010), Р. Аппазова (Аппазов, 2001), трехтомное издание воспоминаний о депортации (Депортация крымских татар, 2004, 2005, 2008) и на крымскотатарском языке - мемуары Н. Хайрединова-Нузетова (Хайрединов-Нузетов, 2008) и С. Эреджепова (Эреджепов, 2012). Период с 2014 г., после возвращения Крыма в состав России, ознаменовался выходом воспоминаний Н. Халилова (Халилов, 2016) и очередным изданием мемуаров Э.У. Чалбаша (Чалбаш, 2017).
\end{abstract}

\footnotetext{
${ }^{*}$ Corresponding author

E-mail addresses: turahu@inbox.ru (V.E. Polyakov)
} 
За исключением воспоминаний Н. Халилова, все остальные издавались без научного редактирования и соответствующих комментариев, что неизбежно влекло к публикации недостоверной информации, повторов, искажений. В трехтомнике воспоминаний о депортации в разных томах использовались воспоминания одного и того же человека (Депортация крымских татар, 2004: 109; Депортация крымских татар, 2005: 152). Здесь также указывается, что: «В партизанском отряде Сейдаша Ибрагимова было уже триста татар» (Депортация крымских татар, 2005: 11). Но в документах Государственного архива Республики Крым партизанский отряд Сейдаша Ибрагимова не значится, как не значится и отряд, в котором бы состояло 300 татар. В уже посмертном издании мемуаров Э.У. Чалбаша его имя Эмир-Усеин заменено на Эмир. Этот перечень ошибок можно было продолжать.

Библиотекой имени Гаспринского все эти годы проводилась большая работа по сохранению письменных источников. Как результат, в ее фондах хранятся не опубликованные и не изученные пока уникальные воспоминания: авиаконструктора Якуба Бекирова (РКБ. ОРКРиАМ. Ф. 99. Оп. 2. Д. 1); школьного учителя, а в войну боевого офицера Девлетова Али (РКБ. ОРКРиАМ. Ф. 4. Оп. 2. Д. 1), которые к тому же содержат уникальные иллюстрации периода войны. Уже упоминавшиеся воспоминания певицы Сабрие Эреджеповой (РКБ. ОРКРиАМ. Ф. 8. Оп. 1. Д. 1.), которые еще ждут своего перевода на русский язык.

Занимаясь много лет историей крымскотатарского народа, регулярно встречаясь с сотнями людей, котором не безразлична история их семьи, я стал обладателем воспоминаний Н. Халилова, которые впоследствии были изданы в Москве и вызвали большой позитивный резонанс. В 2021 г. мне были переданы воспоминания Зекерья Асанова. В настоящее время (на апрель 2021 г.) он жив, относительно здоров.

Родился 3. Асанов в 1930 г. в Евпатории, где находился в годы оккупации, став невольным свидетелем событий Холокоста. Далее - депортация, детский дом, жизнь в условиях комендантского режима. Его воспоминания представляют огромную ценность. Изложены они с небольшой редакторской правкой, выразившейся в изъятии повторов и приведении излагаемых событий в соответствующую хронологическую последовательность. Часто употребляемые автором тюркизмы сохранены, но снабжены комментарием.

В публикуемый текст внесена незначительная литературная правка, он приведен в соответствие с современными правилами орфографии и пунктуации. Сокращения или пропуск слов автором восстановлены публикатором и взяты в квадратные скобки.

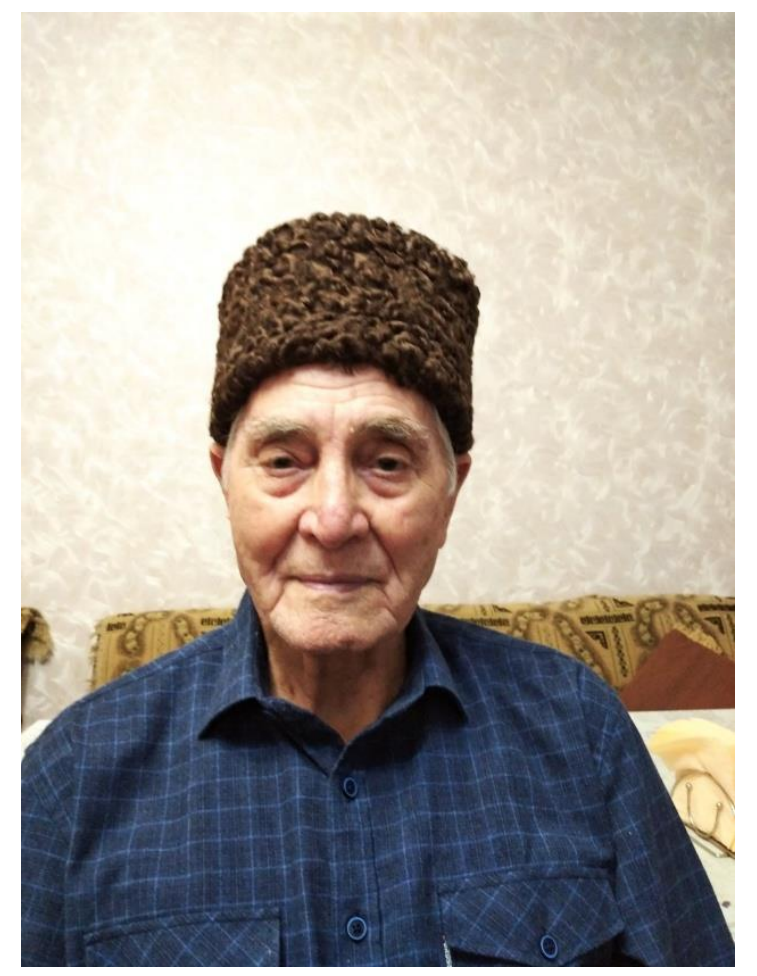

Рис. 1. 3. Асанов. Фото В.Е. Полякова 
Я, Асанов Зекерья, родился в 1930 г. Моего отца звали Асан Джан-Клыч. Он родился в 1882 г. в Евпаторийском районе село Айрча. Отец был родом из дворян. Моя мама имела девичью фамилию Тулубеева и тоже была дворянского происхождения.

Дедушку звали Ислям Тулубеев. Родился он в селе Курт-бей. В данный момент этого села нет, его снесли в 1928-1930 гг. Его жена Исляма Карт-баба Джан-Султан была турчанка. Мой дедушка привез мою бабушку из Турции. Она умерла турецкой подданной.

Я родился в Евпатории, переулок Ломаный, 20. Дом наш и по сей день находится там. Моя мама родилась в 1886 г. в селе Карт-бей. У моей бабушки Джан-Султан было 16 детей, из них 6 умерли, а 10 остались живы.

Моя мама родила 12 детей, из них в живых осталось 7 детей. Перечисляю: Касыс-ага. Родился в 1909 г. Садык - в 1912 г. Сестра Софье - в 1916 г. Шевкет - в 1922 г. Ильяс в 1925 г. Ягья - в 1927 г. Последним потомком был я, Асанов Зекерья. Родился 20 мая 1930 г.

Моя мама как-то сказала мне: «Сынок, ты теперь Джан-Клыч, а по метрике БейАрсланов». Так как ее дедушка просил, чтобы хоть кто-то из внуков сохранил его фамилию. У меня сохранилась метрика, где по-русски и по-татарски написано Бей-Арсланов Асан оглы, Асан-оглы Зекерья, 1930 г.

Я очень хотел знать, кем был мой дедушка, но мама об этом не рассказывала, а я очень жалел, что про дедушку ничего не знаю.

Мой отец Асан Джан-Клыч умер в 1936 г. в день, когда была принята первая Конституция СССР. Брат Касыс в 1931 г. поступил в комсомол. Когда об этом узнал отец, у них был серьезный разговор между ними. После этого брат Касым ушел из дома и стал проживать в городе Челябинске. После смерти отца брат нашу фамилию переименовал на имя отца и с 1936 г. мы все стали именоваться Асановыми.

Второй брат Садык Асанов окончил 4 класса. Потом пошел учиться на парикмахера. Работал в Евпатории на улице Революции около банка. Он был главным кормильцем в нашей семье.

Брат Шевкет, 1922 г.р., до войны работал на ремзаводе в Евпатории, а с 1940 г. на хлебозаводе слесарем.

Брат Ильяс, 1925 г.р., окончил 7 классов и перед самой войной был послан на уборку урожая в Черноморский район ${ }^{1}$ село Садыр-Багай.

Брат Ягья, 1927 г.р., до войны закончил 5 классов.

Я в 1941 г. окончил 3 класса русской школы № 2 г. Евпатория.

В 1941 г. в июне месяце началась война. Брата Садыка сразу забрали в Красную армию. Брата Шевкета в армию не взяли, так как у него была небольшая травма глаза.

Брату Ильясу в селе Садыр-Багай после уборки урожая предложили сопровождать колхозный крупный скот в г. Керчь с одним таким же, как он, крымским татарином. Брату дали около 500 голов (коровы и бычки). Пока дошли до Керчи, у них оставалось около 300 голов, так как часть разбежалась, часть украли. Они сдали скот органам, его стали грузить в баржи и отправлять в Новороссийск. При глазах брата началась бомбежка, и самолеты потопили баржу со скотом. Обо всем этом он мне потом рассказывал.

Когда началась война, в городе как таковых воинских частей не было. Евпаторию сдали без боя. Два дня никого из начальства не было. Очень многие жители эвакуировались. Население грабило магазины, государственные учреждения, санатории. Мой брат Шевкет в то время работал на хлебозаводе. Моя мама пошла проведать брата, но не нашла его, и увидела, что вокруг валялись буханки хлеба. Мама плакала, собирала хлеб в фартук и плача пошла домой.

Брат Шевкет принес домой два мешка муки, полфляги подсолнечного масла и полбочки не то керосина, не то бензина.

Немцы в город въехали на мотоциклах. Их встречали с хлебом и солью русские женщины, ни одного крымского татарина среди встречающих не было.

До вступления немцев в город брат Ягья находился у тети Мевы в Ах-Шейхском районе в селе Угуз-Оглы. Через несколько дней вместе с ней они пошли в Евпаторию, но у шлагбаума немцы его задержали. Сказали, что он похож на еврея. Посадили в комендатуру. Тетя Мева в слезах пришла к нам и рассказала о случившемся. Брат Ильяс тут же пошел

${ }^{1}$ В описываемый период район назывался Ак-Мечетский. 
выручать брата в комендатуру. Когда он туда вошел, его тут же арестовали и повели в подвал. Когда его вели, он случайно встретил там нашего соседа Анатолия по кличке Соган (лук). По-татарски сказал, что в подвале находится его брат Ягья. Толик пошел к кому-то и вскоре Ягью освободили.

Ильяса отправили грузить песок, который отправляли в Германию. Один охранник сказал, что с последним вагоном их тоже отправят в Германию. Ильяс убежал и поселился в деревне, в которой работал до войны.

Немцы сразу, как только заняли город, всех евреев взяли на учет. Заставили носить на груди и на спине черные шестиконечные звезды. Евреи не имели права прямо смотреть на немцев. Если они встречали их на улице, то еврей должен был опустить голову. Немец мог остановить еврея и заставить его вытереть его сапоги. Запрещалось им ходить по тротуару. Через некоторое время объявили, что евреев будут отправлять в трудовые еврейские лагеря, и сказали взять с собой только драгоценные вещи ${ }^{1}$. Сбор был назначен в здании военкомата. Я и мой соседский товарищ пошли провожать нашего друга еврея. Его звали Юся. Мы с Юсей и его родителями дошли до военкомата, который находился за городом у железнодорожной станции. Райвоенкомат - очень большое здание, вокруг него решетчатый забор.

Мы - ребятишки - баловались и играли во дворе военкомата. Вдруг слышим, что подъехали автомашины, из которых вышли немцы. Все евреи забежали внутрь здания. Их было примерно человек 80о. Мы с другом тоже вошли в здание. Быстро закрылись двери, и мы оказались в какой-то комнате. Меня увидел отец Юси и удивленно спросил: «А вы что здесь делаете?». Он открыл окно и выбросил нас с другом на улицу. Мы перелезли через решетку и оказались вне территории военкомата.

Немцы разбили двери и выгнали всех евреев во двор. Стали отделять мужчин в одну сторону, женщин и детей в другую. Детей 2-5 лет отдельно. Затем принесли какое-то черное ведро и стали палкой, обмотанной тряпкой, мазать рот детям. Они тут же падали мертвыми. Женщины рвались к ним и плакали. Затем приехали еще несколько машин. В них загрузили мужчин и куда-то увезли. Вскоре мы услышали выстрелы. Мы с другом побежали на выстрелы и увидели, что мужчин-евреев раздели догола и расстреляли. Затем подъехала машина, из которой вывели еще мужчин. Их заставили закопать расстрелянных, а затем тоже заставили раздеться и расстреляли. Потом приехали машины с женщинами, с ними поступили также. Расстреливали в противотанковом рву, который был метра 3 в ширину и 2 метра в глубину. Это все я видел своими глазами и не могу никогда забыть.

Высадился десант. Один корабль немцы потопили, а второй высадил моряков, человек 800. Все матросы были молодые, лет по 17-20 и все были под градусом (т.е. немного пьяные). Немцев в городе было очень мало, да еще батальон румын. Все они тут же убежали в сторону города Саки. Десантники были вооружены очень хорошо, у них была одна зенитная пушка и танкетка. Десантники призвали население помочь организовать постройку оборонительных укреплений. В мешки собирали песок, рыли окопы, строили баррикады. Шевкет рыл окопы. Город стали обстреливать из пушек, самолеты обстреливали из пулеметов.

Моя бабушка жила недалеко от морского порта в большом жэковском² доме. Дом был очень большой, и в нем проживало человек сто. В этом доме десантники организовали свой главный штаб. Утром мама послала меня проведать бабушку и, если там опасно, увести ее к нам. В ее комнате лежал раненый моряк, в других комнатах тоже. Бабушкина дочка Пембе была медсестрой и оказывала им помощь. Я вернулся домой и все рассказал маме. Она послала Ильяса забрать бабушку к нам, но она отказалась. Немцы окружили дом и тогда десантники предложили Пембе и бабушке уйти. Бабушка отказалась. Десантники долго отстреливались, пока немцы из огнеметов не зажгли дом. Бабушка Джан-Султан сгорела. Все это было на глазах Пембе, которая пряталась в подвале соседнего дома.

В часа два дня пришел домой Шевкет. В руках у него была винтовка, а на плечах пулеметные ленты. Он сказал, что очень голоден. Мама стала ему готовить обед. Он поставил винтовку в угол и сел обедать. Я подошел к винтовке и хотел ее посмотреть, но брат

\footnotetext{
${ }^{1}$ Такие объявления появились 20 ноября 1941 г.

2 ЖЭК - жилищно-эксплуатационная контора. Создавалась для обслуживания типовых домов государственного жилого фонда.
} 
как закричит на меня: «Не трогай, она заряжена!» Я обиделся и пошел во двор. На улице стояли два немца. Один из них был раненый, второй ему оказывает помощь. Я вернулся домой и сказал брату, что на улице немцы. Он тут же унес винтовку в туалет. Когда он вернулся, пришли немцы и его арестовали. Вечером он вернулся, но вновь пришли немцы и его опять арестовали.

Всех жителей выгнали из дворов и погнали по улице Интернациональной в сторону Катыкбазара, потом шли по улице Революции. У русской церкви уже стояло человек 20030о. Мы шли толпой, а сзади вооруженные немцы. У церкви нас продержали полчаса, а потом отпустили по домам.

Утром часов в 5-6 к нам снова пришли немцы, и всех опять выгнали во двор. Сразу забрали обоих моих старших братьев. Меня тоже хотели взять, но мама обняла меня и не отдала немцам. Братьев и всех мужчин погнали в сторону Пересыпи - это в конце города, где была конечная остановка городского трамвая. Там всех мужчин загнали за колючую проволоку, а вокруг стояла немецкая охрана.

Утром мама послала меня разыскивать братьев. Мы, 5-6 соседских ребят, быстро их нашли и увидели, что наши родственники стоят за колючей проволокой. Об увиденном, я рассказал маме. Она дала мне хлеба, и я отнес его братьям. Здесь уже было много женщин и детей, которые тоже передавали продукты, точнее, кидали через проволоку. Так, они простояли там дня два или три. Затем из Симферополя приехала делегация Мусульманского комитета ${ }^{1}$ и стала уговаривать отпустить крымских татар.

Немцы согласились, но при условии, что все, кого освободят, пойдут добровольно служить в немецкую армию. Сейчас они могут идти по домам, но утром должны придти в Хан-Джами․․

Как только Шевкет и Ильяс оказались дома, они переоделись и ушли в ночь. Утро в Хан-Джами пришел только один человек, все остальные разбежались, а вот оставшихся расстреляли.

Спустя неделю после этих событий Пембе обратилась к властям за разрешением откопать останки ее мамы и похоронить. Немцы не возражали.

Мама сказала нам, что у бабушки было девять золотых монет - червонцев, и было бы хорошо их найти. Мы стали раскапывать развалины. Нашли обгоревшее тело в матросской шинели, а в другом углу на сгоревшем теле нашли мешочек и в нем девять золотых монет. Хоронили бабушку все наши родственники и соседи.

В городе был голод. Воды не было, так как, когда наши отступали, то взорвали водонапорную станцию. Мы оставались без воды. На весь район была одна колонка, вода в которую поступала из глубокой скважины. Чтобы взять два ведра воды, мы стояли в очереди по 2-3 дня. В 1943 г. в марте мы переехали в село Садыр-багай, где уже находился мой брат Ильяс. Мы взяли из дома только матрасы, полушки, одеяла, посуду и переехали в деревню.

Там нас приняли очень хорошо, дали нам дом, в котором никто не жил. В нем было две комнаты размером 3 х 4 метра и еще комната, но не жилая. Полов не было. Соседи нам принесли мясо, яйца, молоко и даже большие круглые буханки хлеба. Ильяс принес два мешка пшеницы и барана, которого ему дали за то, что он участвовал в уборке урожая еще при Советах летом 1941 г.

Шевкет и Ильяс часто уходили из дома и прятались от немцев, так как молодежь их возраста угоняли в Германию на работу.

В апреле 1944 г., когда пришли наши войска, они пошли в военкомат. Мы подумали, что их призвали в Красную армию, но как выяснилось потом, они попали в какую-то трудовую армию3.

18 мая 1944 г. утром в часов 5 или 6 постучали к нам в двери. Мама быстро оделась, открыла. В дом вошли офицер и два красноармейца с автоматами. Офицер зачитал какой-то

\footnotetext{
1 Симферопольский мусульманский комитет - крымскотатарская коллаборационистская организация, действовавшая на территории оккупированного Крыма в годы Великой Отечественной войны

${ }^{2}$ Хан-Джами - мечеть.

3 Система принудительной трудовой повинности населения СССР, призываемого в организованные по военному образцу трудовые организации во время Великой Отечественной войны.
} 
приказ о том, что мы - крымские татары - являемся предателями, что мы, якобы, помогали немцам и сказал, что нам дается 15 минут на сборы.

Мама стала плакать и говорить офицеру то по-русски, то по-татарски, что у нее два сына в Красной армии. Офицер сказал, что ничего не знает: Он исполняет приказ командования. Мама продолжала плакать, но стала собирать вещи. Если бы мы были в Евпатории, то еще можно что-то выбрать из нужного, а здесь, в деревне у нас ничего почти не было. Мама вытряхнула из матраса солому, и стала в него складывать, что попадет на глаза. Офицер увидел этот длинный матрас и сказал: «Ты, бабуля, с ума сошла? Вам придется топать пешком 2 или 3 километра. Он выгнал нас из дома, запер дверь на замок и ничего не дал взять с собой. Мы вышли на улицу. Шел проливной дождь. Нас пригнали в школу, где уже было много народа. Кто-то успел разместиться в классах, а остальные стояли под дождем на улице.

В деревне стоял такой шум, что этого невозможно описать: крики, плач, рев коров, вой собак... Так под дождем мы простояли до 5 часов, пока за нами не приехали три автомашины, американские «Студебеккеры». Нас всех посадили в кузова автомашин и повезли в сторону Донузлава. Вслед за машинами долго бежали домашние собаки, выли, лаяли. Мы все плакали.

Вскоре я понял, что нас привезли в Евпаторию. Замелькали родные улицы. Машины шли в сторону «Сольпрома», остановились около железнодорожной платформы. Море было от нас совсем рядом, где-то 50-6о метров. Кто-то высказал предположение, что, наверное, всех нас здесь и расстреляют или утопят в море. Через какое-то время послышался гудок паровоза, который привез товарные вагоны. Красноармейцы стали нас закидывать в товарные вагоны, так как никаких лестниц не было, а высота была 2-2,5 метров, сам не заберешься.

Когда мы оказались в вагоне, то увидели, что он был весь в говне, так как еще недавно в нем перевозили скот. В вагоне оказалось примерно человек 40-50. Большинство было вынуждено стоять. Двери вагонов закрыли. Дышать стало нечем. Было маленькое окошко, но от него не было толку. Сколько мы простояли, я не помню. Наконец, раздался гудок паровоза и поезд тронулся. Ехали 2 или 3 дня. Двери вагона не открывались. Туалета не было. У кого-то оказался топор. Им в углу вагона вырубили дырку, оградили это место простыней и таким образом сделали туалет.

Один мальчик, который смотрел в окошко, закричал, что мы проехали Мелитополь. Вскоре поезд остановился. Двери вагонов открыли солдаты. Наш вагон стоял возле водокачки. Все побежали набирать, кто во что, воду.

Мама тихонько сказала мне и брату, что в Мелитополе живет ее дядя Усейин-даим ${ }^{1}$ и нам надо бежать из поезда к нему. Мы стали готовиться к побегу, как какой-то мужчина, он был старшим по вагону, предупредил, чтобы мы не вздумали бежать, так как нас сразу же убьют. Оказывается, ему кто-то уже донес.

Поезд вновь отправился в неизвестном для нас направлении. Никакой помощи никто не оказывал, никакой еды не давали. Медицинской помощи не было. На остановках люди готовили, что у кого было. В поисках воды часто кто-нибудь отставал, что с ними было, не знаю. Один дедушка умер, и на первой остановке его вынесли и оставили на перроне, а поезд пошел дальше.

Так мы ехали почти месяц. Наконец, приехали на станцию Курган-Тюбе Андижанской области ${ }^{2}$. Мы были в Средней Азии. Солдаты открыли вагоны, рядом стояли какие-то люди во всем белом, как мне показалось, с винтовками в руках. Потом оказалось, что это были

\footnotetext{
1 Даим - брат матери.

2 Город Курган-Тюбе располагается в Таджикистане, с 2018 г. называется Бохтар, является административным центром Хатлонской области. Андижанская область располагается на востоке Узбекистана. Возможно, автор воспоминаний имел в виду не располагавшийся на расстоянии свыше 700 км от Андижанской области Курган-Тюбе, а созвучный ему по названию и входивший в ее состав поселок Кургантепа (с 1976 г. - город) - административный центр Ворошиловского района. Он находится на расстоянии около 10,5 км от поселка Аим.
} 
палки, которыми они зачем-то вооружились. Нас пешком погнали в райцентр Аим ${ }^{1}$. Больных и тех, кто не мог идти, посадили на узбекские двухколесные телеги. Из райцентра Аим нас пешком отправили в колхоз «Социализм». Нас с мамой определили к какой-то узбечке. Она жила одна. Показала нам нашу комнату. Она была размером 3 х 4 метра, в одном углу была большая дыра, сквозь которую было видно небо. Мы сели отдохнуть на земляной пол, как вдруг с потолка прямо на нас упала большая змея. Мы испугались и выбежали во двор. Хозяйка нас успокоила, что эта змея не ядовитая. Хотя она говорила по-узбекски, но мы поняли.

Днем мы находились во дворе под большим абрикосом. Несколько дней никто не приходил, и мы были предоставлены сами себе. Потом пришел мужчина в полувоенной одежде и сказал, что он комендант, и без его разрешения мы никуда не можем ходить за пределы комендантского участка.

Затем он сказал матери, что она должна сходить в правление колхоза и получить паек. Мама ушла и вскоре принесла 10 кг муки. Потом выяснилось, что кладовщик нас обманул он дал 10 кг, а написал 100 кг.

Кто-то из соседей сказал, что маме положена материальная помощь, так как два ее сына на фронте. Она несколько раз ходила в военкомат, но все без толку.

Мама много курила. У нее был чубук - татарская длинная трубка. Это была трубка еще моей бабушки. Туда она засыпала измельченный табак.

Вскоре мама заболела дизентерией, сильно похудела, ей стало очень плохо. Я пошел к председателю и попросил арбу, чтобы отвезти ее в больницу. Двухколесную арбу дали. Я постелил на пол солому, с трудом уложил маму. Пока катил телегу, мама пару раз падала. Ей становилось все хуже. В больницу маму взяли. Когда я пришел через два дня ее проведать, то ей было немного лучше, но дизентерия не прошла. Я приходил каждые 3-4 дня. Однажды она сказала, чтобы я отвез ее домой, так как она хочет умереть рядом с детьми.

Я снова попросил арбу, председатель дал. Дома маме стало чуть лучше, но заболел малярией мой младший брат Ягья. Его трясло, он терял сознание. Чтобы чем-нибудь их кормить, я утром уходил на поля и собирал колоски пшеницы, ячменя, сушенный тутовник и вечером что-то для них готовил. Брату становилось лучше только с заходом солнца.

В середине августа я возвращался со своего очередного похода, как увидел, что у дверей меня ждет сосед Айтвай. Он сказал, что мама велела отвезти меня в детский дом. Я вырвался и побежал к маме. Она подтвердила, и сказала, что скоро умрет, а меня еще можно спасти. Велела, чтоб я не забывал, что у меня есть старшие братья, что скоро кончится война, и они меня найдут. Если я ее сейчас не послушаюсь, то она меня проклянет. Я слышал о таком проклятии, очень испугался и согласился.

Когда мы с соседом приехали в детский дом № 6, то меня отказались принять. Директор, казанский татарин, сказал, что есть приказ, запрещающий принимать крымских татар². Айтвай расстроился, говорит: «Что же мне делать? Брать к себе не могу. У самого 4 девочки, он мне не нужен». Предложил оформить меня, как подкидыша, а национальность написать узбек. Так и сделали. Я стал Хасанов Закир, 1930 г.р. Меня поместили в большую комнату размером примерно 4 х 5 метров, в которой стояло 15 железных коек. Все ребята были узбеки. Также были эвакуированные из Ленинграда мальчики и девочки. Им было лет по 16-17. Нас, местных ребят, они обижали, били, называли черножопыми.

Кормили нас очень плохо. Утром давали 150 грамм хлеба и в обед какую-то жидкую похлебку из пшеничной муки. Вечером нам давали одну маленькую лепешку из крупы, которую называли джугара.

Хлеб, который давали утром, я съедал только 50 грамм, а 100 грамм оставлял маме и брату. Собрав 200 грамм, я, ничего никому не говоря, бежал домой. Мама также лежала под деревом, а брат рядом без сознания.

Вечером, когда я возвращался в детский дом, никто даже не спрашивал, где я был весь день. Потом я стал ждать пока соберется 500 грамм и, уже тогда, убегал к маме. В сентябре

\footnotetext{
${ }^{1}$ В 1929-1959 гг. - районный центр Аимского района. В настоящее время - поселок городского типа в составе Джалалкудукского района Андижанской области Республики Узбекистан.

${ }^{2}$ Наличие такого распоряжения не подтверждается другими источниками.
} 
меня определили в школу. Учились в ней на узбекском языке, но ребята, эвакуированные из Ленинграда, ходили в русские классы, и я стал учиться вместе с ними. Попал в третий класс. Учительницей была молодая красивая девушка. Ей было лет 20-25. Звали ее Надежда. Она сразу догадалась, кто я, но ни разу не спросила о национальности.

17 октября, когда я в очередной раз пришел домой, то услышал, что мальчик на татарском языке созывает людей на похороны. Он кричал, что умерла тетя Эсма, то есть моя мама. Как я дошел до дома, не знаю. Я чуть не упал. Мама лежала под деревом, рядом лежал мой брат. Через какое-то время пришли 5 или 6 человек - наши крымские татары, принесли узбекские носилки. Они были большие и тяжелые. Маму не купали, не читали никаких молитв, а положили на носилки и понесли на кладбище. До него было метров 500. Пока ее несли 2 или 3 раза роняли, так как носилки были тяжелые, а люди были обессиленные. Пришли на кладбище. Могила уже была вырыта. Глубина всего один метр. Грунт каменный. Похоронили. Я остался у могилы один. Поплакал. Взял две ивовые палочки и воткнул у изголовья и ног.

Пришел домой. Брат пришел в себя и спрашивает у меня: «Где мама?» Он даже не знал, что она умерла. Пришел сосед Айтвай и сказал, что брата он возьмет к себе. Если умрет, то похоронит, если выживет, то будет ему как сын. Я попрощался с братом Ягья, и пошел назад в детский дом.

В декабре было очень холодно. В палате была железная печка, но топить было нечем. По вечерам мы приносили коробочки с нераскрывшимся хлопком, вскрывали их, очищали, и этими коробочками топили печь.

У всех ребят появились вши. В баню нас зимой не водили. Когда печка горела, мы снимали рубашки, подходили к раскаленной печке и трясли свои рубашки. Стоял треск от сгоравших вшей. Я стал очень слабым и в школу уже не ходил, так как не было сил. Однажды мне не принесли в палату обед, и тогда я пополз сам. Где на четвереньках, где ползком добрался до столовой, но войти не мог, так как порог был очень высокий, сантиметров 30-40. Повара подняли меня, занесли в столовую и накормили. Потом на руках отнесли в палату.

Один мальчик - узбек, был очень шустрый. Он куда-то уходил за пределы детского дома и приносил в палату морковь, репу, шалгам ${ }^{1}$. Мы меняли ему свой хлеб на эти овощи. Я стал пухнуть и совсем обессилил. Попробовал пощупать щеку и получилась ямочка от пальцев. Потом она рассасывалась целый день.

Мне стало так плохо, что я потерял сознание. Подумав, что я умер, меня отнесли в палату к умершим. Там я пролежал какое-то время, очнулся. Смотрю: лежу на железной решетке без матраса. Рядом еще кто-то лежит. Потрогал, а он мертвый. Я хотел перелезть через него, но снова потерял сознание. Очнулся уже в больнице. Дня через три пришла моя учительница Надежда. Оказывается, она приходила в детский дом, и, узнав, что я в больнице, пришла сюда. Он принесла мне хлеб, масло, колбасу и заставила все это съесть при ней, так иначе все это украдут. Она каждое утро до работы заходила ко мне и кормила. Вечером тоже приносила что-нибудь домашнего. Я стал поправляться. Потом меня выписали из больницы. Надежда забрала меня к себе на квартиру, она жила у какой-то узбечки, а утром отвела в детский дом. Там меня не хотели принимать, так как по всем документам я уже умер. Тогда меня оформили заново. Надежда каждое утро приносила мне хлеб, масло, колбаску... Так продолжалось дней 10-15.

Когда она утром приходила, дети кричали: твоя мама идет. Я краснел, и мне было неудобно слушать, что ребята так говорили. Я ростом был не очень высок, и лицо было все в морщинах. Мне дали кличку «Бабай», то есть «Старик». По имени меня никто и не звал. Только «Бабай».

Через какое-то время я заметил, что моей учительницы долго не было. Я пошел к ней в школу, но мне сказали, что она больше не работает. Я пошел на квартиру и узнал, что она вышла замуж и куда-то уехала. Так я потерял спасительницу моей жизни.

В 1945 г. окончилась война. Всех эвакуированных отправили назад в Ленинград. После этого мы спокойно вздохнули, так как никто нас не обижал, не бил.

${ }^{1}$ Шалгам - фиолетовая редька. 
Около детского дома было много тутовых деревьев. Мы собирали их плоды и ели, когда шелковица поспевала. Нашему детскому дому колхоз выделил земельный участок. Мы засеяли его семенами риса. По-узбекски он назывался шала. Когда рис вырос, мы все выходили на поле и вырывали сорняки, которые росли в большом количестве. Урожай убирали сами колхозники, но весь рис отдавали детскому дому. Еще мы помогали Райшелку ${ }^{1}$ выращивать шелковичных червей. Из нас создали три группы ребят, которые собирали с тутовых деревьев ветки с листьями и кормили ими шелковичных червей. У нас была тележка и ослик (ишак). Мы его запрягали и на тележке привозили листья для червей. За нашу работу детскому дому давали 2 килограмма риса, полкило моркови, полкило мяса и пол-литра хлопкового масла. Повара из всего этого готовили плов, который очень помог восстановлению моего здоровья. После отъезда ленинградцев русские классы закрыли и потому в школу я не ходил.

В 1948 г. в детский дом приехал представитель училища $\Phi 30^{2}$ из Ташкента и стал отбирать старших ребят для учебы. Я тоже записался. Для тех, кто уезжал в Ташкент, стали выдавать новую одежду, а мне не выдают. Спрашиваю, в чем дело, а он отвечает, что есть приказ крымских татар не принимать.

После окончания войны в детские дома принимать разрешили, и в нашем детском доме появился еще один крымский татарин Якуб. Его тоже не оказалось в списках. Мы с Якубом обняли его за ноги и стали плакать и просить, чтобы он взял нас с собой. Он отказал, оттолкнул нас ногой, а потом вдруг сказал: «Хрен с вами. Я беру вас обоих». Так мы, 15 человек, приехали в Ташкент. Сначала нас привели в приют, где всем выдали узбекские паспорта, в которых мы расписались. Их тут же у нас забрали и отдали коменданту ФЗО. Привели в общежитие, поместили по 10 человек в одной комнате. Утром повели на завод, где строили военные самолеты ${ }^{3}$. Нас закрепили за рабочими. Меня поставили на сверлильный станок. Так мы учились и работали 6 месяцев, а потом нас отправили в совхоз «Баят № 1». Наши паспорта отдали директору совхоза. Меня направили в кузницу, где я каждый день качал горн.

1948 г. был очень холодный, а у меня тоненькая куртка. Кто-то сказал, что здесь недалеко есть базар, где продают домашние вещи. Так как нам платили зарплату, деньги у меня были. Я пошел на базар, а там случайно встретил дядю Мамбета, сына моей тети Айше, которая была сестрой моего отца. Я подошел к нему, поздоровался и назвал, кто я. Он посмотрел на меня и узнал. Я спросил у него, не знает ли он, где находятся мои братья Шевкет и Ильяс, которых забрали в Красную армию. Он рассказал, что они попали не в Красную армию, а в трудовую строительную армию, которая находилась в городе Рыбинск4. Также сказал, что много крымских татар пересилили в Таджикскую республику на станцию Ленинабад 5 .

На следующий день я пришел к директору совхоза и рассказал, что нашел своих родственников и попросил отдать паспорт. Директор достал мой паспорт, положил на стол, но вдруг сказал, что отдать его не может, так как за мной приедут из ФЗО. Вот отработай 6 месяцев, а потом езжай, куда хочешь. В это время раздался звонок на обед. Директор сказал, что продолжим разговор после обеда. Мы вышли, а мои документы остались лежать на столе.

Я не пошел на обед, а прокрался к окну в кабинет директора. Вытащил стекло, но там еще была железная решетка, с которой я ничего не мог сделать. Я сбегал в кузницу, где взял палку и прибил к ней гвоздь. Вернулся к окну. Директора еще не было. Сквозь решетку дотянулся палкой до документов, зацепил гвоздем и потянул к себе. Они приблизились, но затем упали на пол, и достать их я уже не мог. Я вернулся в общежитие, собрал вещевой

\footnotetext{
${ }_{1}^{1}$ Райшелк - Районное управление по производству шелка.

2 ФЗО - фабрично-заводское обучение.

з С 1942 г. завод производил самолеты Ли-2, созданные на основе американского пассажирского самолета DC 3.

4 Второй по величине город в Ярославской области.

5 C 1991 г. - Худжант, административный центр Согдийской области.
} 
мешок и пошел на станцию Мирзачуль․․ Там посмотрел расписание поездов и увидел, что поезд Москва - Андижан проходит в 12 часов ночи. Подошел к кассе и попросил дать мне билет до станции Ленинабад. У меня потребовали паспорт, и, когда узнали, что его нет, то билет не дали. Я остался на вокзале и стал ждать поезда. Вошли два милиционера и стали проверять документы. Я потихоньку вышел на перрон и спрятался в туалете. Там было очень холодно. Дождавшись, когда милиционеры уйдут, я вернулся в зал ожидания. Так происходило несколько раз. Поезд приехал вовремя. Я подошел к проводнику и попросил взять до станции Ленинабад. Сказал, что у меня есть деньги, но нет паспорта. Он отказал. Я шел от вагона к вагону. Один проводник сжалился: «Черт с тобой! Залезай».

Утром я приехал в Ленинабад. Хожу по городу, всматриваюсь в лица людей, ищу похожих на крымских татар. Смотрю, подходит мужчина, вроде, похожий. Я подошел к нему и спросил на русском языке: «Есть ли здесь крымские татары?» Он ответил, что есть, и он тоже крымский татарин. Я спросил: «Не знает ли он об Асановых Шевкете и Ильясе?» Он сказал, что не знает, но посоветовал найти Куртиева Сейт-Абла, который знает очень многих и назвал его адрес: «Поселок Консай, улица Комсомольская, 36». Я нашел этот поселок, этот дом. Постучал в дверь. Вышла молодая, красивая женщина и спросила, что я хочу? Я заплакал, обхватил ее ноги и стал спрашивать, не знает ли она о моих братьях Шевкете и Ильясе.

Она сразу поняла, кто перед ней. Оказалось, что она моя двоюродная сестра по материнской линии. Вечером пришел с работы дядя Сейт-Абла и, когда стемнело, он отвел меня к мои братьям Шевкету и Ильясу. Они узнали меня, мы обнялись и стали плакать от радости.

На следующий день Шевкет посадил меня возле себя и рассказал, что крымские татары раз в месяц должны отмечаться у военного коменданта, что татарам нельзя появляться на железнодорожной станции. Нельзя там даже купить кружку пива. Один наш татарин выпил на вокзале кружку пива, и его арестовали. Дали 10 лет за побег. Мы договорились, что я буду говорить, что я 1934 г.р. и потому на меня комендантский режим пока не распространяется.

Я вновь пошел учиться. Приняли меня в 4 класс. Было очень тяжело, но я не сдавался. Со мной за партой сидел русский парень Николай, такой же переросток. Он приехал из Калужской области с матерью, к своему отцу, который тут отбывал наказание, как побывавший в плену. Мы подружились. Он бывал у меня дома, я у него. В 1949 г. Николай предложил написать заявление в комсомол. Я ответил, что это бесполезно, так как меня не примут из-за того, что я крымский татарин, да и его тоже не примут, так как его отец был в плену. Николай не поверил и сказал, что сын за отца не отвечает. Он подал заявление в комсомол. Было какое-то бюро, на котором всех заслушивали, в том числе и Николая. Когда утром я пришел в школу, то Николая в классе не было. После занятий я пошел к нему домой и увидел, что он лежит на диване: плачет, ругается, проклинает всех. Через несколько дней он уехал к себе на родину. Мы переписывались. Вскоре он сообщил, что его приняли в комсомол.

Я окончил 7 классов и пошел поступать в Ленинабадское авиационное училища. Написал заявление, но мне сказали, что крымских татар не принимают. Я расстроился, побродил по городу и увидел объявление о приеме в медицинский техникум. Там мои документы тоже не приняли. Иду дальше. Увидел сельскохозяйственный техникум. Там документы приняли, и я стал готовиться к экзаменам. Жил у моих родственников. Экзамены сдал на «хорошо» и «отлично», но в списках принятых меня не оказалось. Секретарь приемной комиссии объяснить не могла и отправила к директору. Он сказал, что сверху есть указание - крымских татар не принимать, так как вам запрещено выезжать, а выпускники техникума поедут в другие районы республики.

Обо всем этом я рассказал тете Нияре, у которой жил. Она ничего не сказала, но взяла меня за руку, и мы опять пошли в техникум. Она вошла в кабинет директора, а я остался в приемной. Я нарочно ногой не дал закрыться двери и потому слышал, о чем они говорили.

Тетя Нияра спросила: «Почему ее племянника не приняли учиться?» Директор ответил, что он уже все объяснил. Тогда тетя Нияра сказала, что какое ему дело до того, что

\footnotetext{
1 Поселок Мирзачуль в 1961 г. преобразован в город Гулистан. В настоящее время -
} административный центр Сырдарьинской области Узбекистана. 
будет делать ее племянник через четыре года. Все это она говорила на таджикском языке. Директор долго молчал, а потом сказал, что отдаст приказ о моем зачислении.

Так, благодаря тете Нияре, я стал учиться в техникуме. Меня поселили в общежитие. В комнате было 12 человек. Был казанский татарин, башкирский, я - крымский, все остальные ребята - русские. Меня выбрали старостой группы, а затем и старостой духового оркестра. В 1952 г. ко мне подошел комсорг и предложил вступить в комсомол. Я ответил, что я - крымский татарин и меня не примут. Через несколько дней он опять подошел и сказал писать заявление. В райкоме комсомола мне предложили рассказать биографию. Я рассказал, как от голода и болезней умерла моя мама, что два моих старших брата погибли на войне ${ }^{1}$.

Секретарь горкома спросил, хочу ли я быть комсомольцем?

Я ответил, что да. Меня приняли единогласно.

В 1955 г. я окончил техникум. Потом, уже заочно, Ташкентский сельскохозяйственный институт.

В настоящее время живу в селе Михайловка Сакского района. Имею сына Зенура и дочерей Зеру и Земфиру, 9 внуков и 5 правнуков.

\section{Литература}

Аппазов, 2001 - Аппазов Р.Ф. Следы в сердце и в памяти. Симферополь: Доля, 2001. $336 \mathrm{c}$.

Арифов, 1990 - Арифов Э.Д. Записки военного коменданта. Документальные очерки, воспоминания, повести. М.: Сов. писатель, 1990. 336 с.

Асанов Касим - Асанов Касим. Учетно-послужная карточка [Электронный ресурс]. URL: https://pamyat-naroda.ru/heroes/kld-card_uchet_officer5010380 (дата обращения: 17.12.2021).

Асанов Садык Асанович - Асанов Садык Асанович. Документы о награждении [Электронный pecypc]. URL: https://pamyat-naroda.ru/heroes/podvig-chelovek_kartoteka142 2582529 (дата обращения: 17.12.2021)

Депортация крымских татар, 2004 - Депортация крымских татар 18 мая 1944 года. Как это было (воспоминания депортированных). Симферополь: Оджакъ, 2004. 316 с.

Депортация крымских татар, 2005 - Депортация крымских татар 18 мая 1944 года. Как это было (воспоминания депортированных). Симферополь: Оджакъ, 2005. 304 с.

Молла, 1978 - Молла A. Мушкюльеллар. Ташкент: Гъафур Гъуламадына эдебият ве санъатнешр, 1978. 131 с. (на крымско-татар. яз.)

Ниязиева-Керменчикли, 1971 - Ниязиева-Керменчикли 3. Дагъларбашында: Хатырлавлар. Ташкент: Гъафур Гъуламадына эдебият ве санъатнешр, 1971. 116 с. (на крымско-татар. яз.)

РКБ. ОРКРиАМ - Республиканская крымскотатарская библиотека им. И. Гаспринского. Отдел редких книг, рукописных и архивных материалов

Хайрединова-Нузетова, 2008 - Хайрединова-Нузетова H.T. Такъдирим (Хатырлавлар). Симферополь: Доля, 2008. 152 с. (на крымско-татар. яз.)

Халилов, 2016 - Халилов Н. Долгая дорога домой. Воспоминания крымского татарина об участии в Великой Отечественной войне. 1941-1944. М.: Центрполиграф, 2016. 255 с.

Чалбаш, 1971 - Чалбаш Э.У. Йигирми эки йыл кокте: Арбий летчикнинъ хатырлавлары. Ташкент: Гъафур Гъуламадына эдебият ве санъатнешр, 1971. 160 с. (на крымско-татар. яз.)

Чалбаш, 1996 - Чалбаш Э.У. 22 года в небе (воспоминания летчика-истребителя). Симферополь: Крымучпедгиз, 1996. 224 с.

Чалбаш, 2010 - Чалбаш Э.У. Сковать боем! Советские асы против Люфтваффе. М.: Яуза Эксмо, 2010. 380 с.

\footnotetext{
${ }^{1}$ Асанов Касим (1910-1944) - родился в селе Айрча Евпаторийского района. Служил в РККА с 1939 г., капитан, командир роты тяжелых танков 79-го отдельного гвардейского тяжелого танкового полка, награжден орденом Красной звезды, медалью «За отвагу» (Асанов Касим). Асанов Садык Асанович (1912-1945) - родился в селе Кульст Фрайдорофского района. Служил в РККА с 1939 г., лейтенант, командир взвода в 409-м минометном полку. Награжден медалью «За отвагу» (Асанов Садык Асанович).
} 
Чалбаш, 2017 - Чалбаш Э.У. Крылья вырастают в небе: мемуары. Симферополь: ГАУ РК «Медиацентр им. И. Гаспринского@, 2017. 256 с.

Эмиров, 1983 - Эмиров А.-А. Танъныкъаршылап. Ташкент: Эдебият ве санъат нешр, 1983. 208 с. (на крымско-татар. яз.)

Эреджепова, 2012 - Эреджепова C. Меним энишли-ёкъ ушлы ве чечекли ёлларым (кечмишим ве агъыр такъдирли аятым). Хатыра китабы. Симферополь: Къырым девокъув педнешир, 2012. 248 с. (на крымско-татар. яз.)

\section{References}

Appazov, 2001 - Appazov, R.F. (2001). Sledy v serdtse i v pamyati [Traces in the heart and in the memory]. Simferopol': Dolya, 2001. 336 p. [in Russian]

Arifov, 1990 - Arifov, E.D. (1990). Zapiski voyennogo komendanta. Dokumental'nyye ocherki, vospominaniya, povesti [Notes of the military commandant. Documentary sketches, memoirs, stories]. M.: Sov. pisatel', 1990. 336 p. [in Russian]

Asanov - Asanov Kasim. Uchetno-posluzhnaja kartochka [Asanov Kasim. Registration and service card] [Electronic resource]. URL: https://pamyat-naroda.ru/heroes/kld-card_uchet_offic er5010380 (date of access: 17.12.2021) [in Russian]

Asanov - Asanov Sadyk Asanovich. Dokumenty o nagrazhdenii [Asanov Sadyk Asanovich. Awarding documents [Electronic resource]. URL: https://pamyat-naroda.ru/heroes/podvig-chelov ek_kartoteka1422582529 (date of access: 17.12.2021) [in Russian]

Deportatsiya krymskikh tatar, 2004 - Deportatsiya krymskikh tatar 18 maya 1944 goda (2004). Kak eto bylo (vospominaniya deportirovannykh) [Deportation of the Crimean Tatars on May 18, 1944. How it was (memories of the deportees)]. Simferopol': Odzhak", 2004. 316 p. [in Russian]

Deportatsiya krymskikh tatar, 2005 - Deportatsiya krymskikh tatar 18 maya 1944 goda (2005). Kak eto bylo (vospominaniya deportirovannykh) [Deportation of the Crimean Tatars on May 18, 1944. How it was (memories of the deportees)]. Simferopol': Odzhak", 2005. 304 p. [in Russian]

Molla, 1978 - Molla, A. (1978) Mushkyul'yellar [Problems]. Tashkent: G"afur G"ulamadyna edebiyat ve san"atneshr, 131 p. [in Crimean Tatar]

Niyaziyeva-Kermenchikli, 1971 - Niyaziyeva-Kermenchikli, Z. (1971) Dag"larbashynda: atyrlavlar [At the top of the mountains: snacks]. Tashkent: G"afur G"ulamadyna edebiyat ve san"atneshr, 116 p. [in Crimean Tatar]

RKB. ORKRiAM - Respublikanskaja krymskotatarskaja biblioteka im. I. Gasprinskogo. Otdel redkih knig, rukopisnyh i arhivnyh materialov [Republican Crimean Tatar Library named after I. Gasprinsky. Department of Rare Books, Manuscript and Archival Materials]

Khayredinova-Nuzetova, 2008 - Khayredinova-Nuzetova, N.T. (2008) Tak\#dirim (Hatyrlavlar) [Thank you (Memories)]. Simferopol': Dolya, 152 p.

Khalilov, 2016 - Khalilov, N. (2016) Dolgaya doroga domoy. Vospominaniya krymskogo tatarina ob uchastii v Velikoy Otechestvennoy voyne. 1941-1944 [Long way home. Crimean Tatar memories of participation in the Great Patriotic War. 1941-1944]. Moscow: Tsentrpoligraf, 255 p. [in Russian]

Chalbash, 1971 - Chalbash, E.U. (1971). Yigirmi eki yyl kokte: Arbiy letchiknin" khatyrlavlary [Twenty-Two Years of Cocktail: Memoirs of a Military Pilot]. Tashkent: G"afur G"ulamadyna edebiyat ve san"atneshr, $160 \mathrm{p}$. [in Crimean Tatar]

Chalbash, 1996 - Chalbash, E.U. (1996). 22 goda v nebe (vospominaniya letchikaistrebitelya) [22 years in the sky (memories of a fighter pilot)]. Simferopol': Krymuchpedgiz, 224 p. [in Russian]

Chalbash, 2010 - Chalbash E.U. (2010). Skovat' boyem! Sovetskiye asy protiv Lyuftvaffe [Chain in battle! Soviet aces against the Luftwaffe]. Moscow: Yauza Eksmo, 380 p. [in Russian]

Chalbash, 2017 - Chalbash, E.U. (2017). Kryl'ya vyrastayut v nebe: memuary [Wings grow in the sky: a memoir]. Simferopol': GAU RK “Mediatsentr im. I. Gasprinskogo”, 256 p. [in Russian]

Emirov, 1983 - Emirov, A.-A. (1983). Tan"nyk"arshylap [By the way]. Tashkent: Edebiyat ve san"at neshr, 1983. 208 p. [in Crimean Tatar]

Eredzhepova, 2012 - Eredzhepova, S. (2012). Menim enishli-yok" ushly ve chechekli yollarym (kechmishim ve ag"yr tak"dirli ayatym). Khatyra kitaby [My paths of prosperity and 
prosperity (a verse of the past and a destiny of destiny). Book of Remembrance]. Simferopol': K"yrym devok"uv pedneshir, 248 p. [in Crimean Tatar]

\section{Воспоминания Зекерья Асанова о Холокосте, депортации, комендантском режиме, а также о хороших людях, с которыми его сводила жизнь}

Подготовка к публикации, вступительная статья и комментарии

Владимир Евгеньевич Поляков а, *

a Крымский инженерно-педагогический университет имени Февзи Якубова, Симферополь, Российская Федерация

Аннотация. Воспоминания крымских татар в советское время редко публиковались. В настоящее время мемуары часто издаются без научного редактирования и комментариев. Впервые публикуются воспоминания 3. Асанова как свидетеля трагических событий Великой Отечественной войны и послевоенного времени. Автор воспоминаний был очевидцев уничтожения евреев в оккупированной немецко-румынскими войсками Евпатории, позже вместе с родственниками и земляками подвергся принудительному переселению. Немало внимания уделяется описанию жизни спецпоселенцев в условиях комендантского режима, быта в детских домах Узбекистана. Наряду с пережитыми трудностями, 3. Асанов подчеркивает атмосферу взаимовыручки и братской помощи со стороны не только крымских татар, но и представителей других национальностей - узбеков, таджиков, русских, с которыми его сводила судьба.

Ключевые слова: Великая Отечественная война, Холокост, Евпатория, депортация, Узбекистан, Таджикистан, комендантский режим, детский дом.

\footnotetext{
* Корреспондирующий автор
}

Адрес электронной почты: turahu@inbox.ru (В.Е. Поляков) 